\title{
Neurotrophic Actions of a Novel Molluscan Epidermal Growth Factor
}

\author{
Petra M. Hermann, ${ }^{1}$ Ronald E. van Kesteren, ${ }^{2}$ Willem C. Wildering,,$^{1}$ Sherry D. Painter, ${ }^{3}$ John M. Reno, ${ }^{5}$ \\ John S. Smith, ${ }^{4}$ Santosh B. Kumar, ${ }^{5}$ Wijnand P. M. Geraerts, ${ }^{2}$ Lowell H. Ericsson, ${ }^{5}$ August B. Smit, ${ }^{2}$ \\ Andrew G. M. Bulloch, ${ }^{1}$ and Gregg T. Nagle ${ }^{3}$
}

\begin{abstract}
${ }^{1}$ Department of Physiology and Biophysics, Neuroscience Research Group, University of Calgary, Calgary, Alberta, T2N 4N1 Canada, 2Department of Molecular and Cellular Neurobiology, Institute of Neuroscience, Vrije Universiteit, Amsterdam, 1081 HV The Netherlands, ${ }^{3}$ Marine Biomedical Institute and Department of Anatomy and Neurosciences and ${ }^{4}$ Protein Chemistry Facility, Department of Human Biological Chemistry and Genetics, The University of Texas Medical Branch, Galveston, Texas 77555, and 5Department of Biochemistry, University of Washington, Seattle, Washington 98195
\end{abstract}

\begin{abstract}
The mammalian epidermal growth factor (EGF) is expressed in the developing and adult CNS, and it has been implicated in the control of cell proliferation, differentiation, and neurotrophic events. Despite extensive evolutionary conservation of the EGF motif in a range of different types of proteins, secreted EGF homologs with neurotrophic actions have not been reported in invertebrates. In this study, we present a novel member of the family of EGF-like growth factors, an EGF homolog from the mollusc Lymnaea stagnalis (L-EGF), and we demonstrate that this protein has neurotrophic activity. Purified L-EGF is a 43residue peptide and retains the typical structural characteristics of the EGF motif. The L-EGF cDNA reveals a unique precursor organization. In contrast to the multidomain mammalian EGFs, it consists of only two domains, a signal peptide and a single EGF
\end{abstract}

Epidermal growth factor (EGF), a member of the EGF growth factor family, is expressed in the developing and adult CNS (Rall et al., 1985; Schaudies et al., 1989; Lazar and Blum, 1992). Mammalian EGF is a polypeptide consisting of 53 amino acid residues characterized by six cysteine residues arranged in a conserved pattern of three disulfide bonds and three characteristic C-terminal amino acids (the EGF motif) (Carpenter and Cohen, 1990). This secreted polypeptide is the product of the proteolytic processing of a large, multi-domain transmembrane EGF precursor protein (Carpenter and Cohen, 1990; Plata-Salamán, 1991; Yamada et al., 1997). The EGF motif is present in many other multi-domain proteins throughout the animal kingdom, including a number of EGF family members, such as transforming growth factor $\alpha$ $(\mathrm{TGF} \alpha)$ and amphiregulin (Engel, 1989; Carpenter and Cohen, 1990; Davis, 1990; Greenwald, 1990; Muskavitch and Hoffmann, 1990; Yamada et al., 1997). Although TGF $\alpha$ homologs have been

Received Feb. 15, 2000; revised May 22, 2000; accepted June 22, 2000.

This work was supported in part by National Science Foundation Grant IBN-9511773 (G.T.N.), grants from the Medical Research Council of Canada, and Human Frontiers Science Program Organization Grant RG0045/1997B. W.C.W. was supported by the Alberta Heritage Foundation for Medical Research (AHFMR) A.G.M.B. is an AHFMR Scientist. The L-EGF sequence has been deposited in the Protein Information Resource-International Protein Sequence Database under accession number A58998. The GenBank accession number for the $L-E G F$ cDNA is AF187041. This work is dedicated to Dr. Michael J. Greenberg, codiscoverer of the first molluscan neuropeptide (FRMFamide) and former mentor (of G.T.N and S.D.P.). We thank Drs. Marijke de Jong-Brink, Pamela de Boer, Nico de With, and Andries ter Maat for kindly providing initial supplies of Lymnaea albumen glands and Eric Schepens for technical assistance. We acknowledge the University of Texas Medical Branch (UTMB) Protein Chemistry Laboratory, which is supported by the UTMB Educational Cancer Center, for amino acid compositional and microsequence analysis.

Correspondence should be addressed to Dr. A. G. M. Bulloch, Department of Physiology and Biophysics, Neuroscience Research Group, University of Calgary, 3330 Hospital Drive NW, Calgary, Alberta, T2N 4N1 Canada. E-mail: bulloch@ucalgary.ca.

Copyright (C) 2000 Society for Neuroscience $0270-6474 / 00 / 206355-10 \$ 15.00 / 0$ motif. Conspicuously, the L-EGF precursor lacks a transmembrane domain, setting it apart from all other members of the EGF-family. L-EGF mRNA is expressed throughout embryonic development, in the juvenile CNS, but not in the normal adult CNS. However, expression in the adult CNS is upregulated after injury, suggesting a role of L-EGF in repair functions. This notion is supported by the observation that L-EGF evokes neurite outgrowth in specific adult Lymnaea neurons in vitro, which could be inhibited by an EGF receptor tyrosine kinase inhibitor. In conclusion, our findings further substantiate the notion that the EGF family has an early phylogenetic origin, and our data support a neurotrophic role for L-EGF during development and injury repair.

Key words: epidermal growth factor; neurotrophic factors; neurite outgrowth; mollusc; development; regeneration. found in Drosophila (e.g., spitz and gurken; Rutledge et al., 1992; Neuman-Silberberg and Schüpbach, 1993), secreted forms of EGF itself have so far only been reported in mammals.

The present study was motivated by the observation that human EGF (hEGF) induces neurite outgrowth in motoneurons of the pond snail Lymnaea stagnalis. This result and the apparent conservation of the EGF motif prompted us to investigate the existence of an EGF homolog in Lymnaea. Although Lymnaea has been successfully used over the last decade to identify growth factor receptors (Roovers et al., 1995; Van Kesteren et al., 1998) and to characterize novel neuromodulatory actions of neurotrophic factors (Wildering et al., 1995; Fainzilber et al., 1996), attempts to identify endogenous growth factors have so far remained primarily unsuccessful. The single exception to this rule is cysteine-rich neurotrophic factor (Fainzilber et al., 1996). In this regard, it is of particular interest to investigate the existence of Lymnaea EGF homologs and their physiological activity.

In the present study, we purified, cloned, and characterized an EGF homolog, Lymnaea EGF (L-EGF) from the Lymnaea albumen gland, an organ that secretes fluid surrounding fertilized oocytes (Joosse and Geraerts, 1983). We show that L-EGF is a secreted growth factor with a surprisingly simple precursor organization. L-EGF selectively induces neurite outgrowth in adult Lymnaea neurons in vitro. An endogenous role for L-EGF in neuronal development and regeneration is suggested by the fact that, in addition to expression in the albumen gland, mRNA expression for this factor is highest during embryogenesis, in juvenile brains, and is upregulated in adult CNS after axotomy. This study shows for the first time that a secreted homolog of the peptide EGF is present in an invertebrate species and likely plays a neurotrophic role during development and axonal regeneration of adult neurons. 


\section{MATERIALS AND METHODS}

Peptide extraction and purification of L-EGF. L-EGF was purified from extracts of $\sim 500$ albumen glands in batches of 10-20 glands. Albumen glands were removed from the adult gastropod mollusc L. stagnalis, lyophilized, extracted at $4^{\circ} \mathrm{C}$ in $0.1 \%$ heptafluorobutyric acid (HFBA) (Pierce, Rockford, IL) using a Polytron homogenizer (Brinkmann Instruments, Inc., Westbury, NY), and sonicated. The extract was centrifuged for $20 \mathrm{~min}$ at 48,000 $\times g$ $\left(4^{\circ} \mathrm{C}\right)$, and the supernatant was purified on four C18 Sep-Pak cartridges (Waters Associates, Milford, MA) connected in series; Sep-Paks were pretreated with $5 \mathrm{ml}$ of $100 \%$ acetonitrile (ACN) containing $0.1 \% \mathrm{HFBA}$ and rinsed with $10 \mathrm{ml}$ of $0.1 \%$ HFBA. The peptides were eluted with $5 \mathrm{ml}$ of $50 \%$ ACN containing $0.1 \%$ HFBA and lyophilized. The lyophilizate was resuspended in $2.5 \mathrm{ml}$ of $0.1 \% \mathrm{HFBA}$ and applied to an analytical $\mathrm{C} 18$ reversedphase (RP)-HPLC column $(4.6 \times 250 \mathrm{~mm}$; Vydac, Hesperia, CA). The column was eluted with a two-step linear gradient of $0.1 \%$ HFBA and ACN containing $0.1 \%$ HFBA. The first step was $0-10 \%$ ACN containing $0.1 \% \mathrm{HFBA}$ in $5 \mathrm{~min}$, and the second step was $10-34 \% \mathrm{ACN}$ containing $0.1 \%$ HFBA in $85 \mathrm{~min}$. The column eluate was monitored at $214 \mathrm{~nm}$, and $1 \mathrm{~min}(1 \mathrm{ml})$ fractions were collected. For chemical characterization studies, fractions containing L-EGF were pooled, lyophilized, reduced with 2-mercaptoethanol, alkylated with 4-vinylpyridine (Pierce) (Hawke and Yuan, 1987; Coligan et al., 1996), and purified by Vydac C18 RP-HPLC. The same gradient conditions were used as described above, except that $0.1 \%$ trifluoroacetic acid (TFA) (Pierce) was the counterion. The peak of interest was characterized by amino acid compositional and microsequence analysis. For bioassays studies, fractions containing L-EGF were not reduced and alkylated before Vydac C18 RP-HPLC. Approximately 175 pmol of L-EGF were obtained per gland.

Amino acid compositional analysis of $L-E G F$. Reagents for these analyses were purchased from PE/Applied Biosystems (Foster City, CA). Compositional analyses were performed using a PE/Applied Biosystems $420 \mathrm{H}$ Amino Acid Analyzer (Smith et al., 1991).

Edman microsequence analysis of $L-E G F$. For Edman degradations of L-EGF, formic acid-treated L-EGF, and Glu-C peptides, samples were applied to Biobrene Plus-treated glass fiber filters and subjected to automated N-terminal sequence analysis using a PE/Applied Biosystems Procise 494/HT Protein Sequencer. Pulsed liquid cycles were used for each analysis. Edman degradations of tryptic and pyroglutamate aminopeptidase (PGAP) peptides were performed using a PE/Applied Biosystems 477A Protein Sequencer connected to an on-line 120A Analyzer using sequencing protocols specified by, and reagents from, the instrument manufacturer. Data analyses were conducted by direct inspection of online analog chart recordings and compared with phenylthiohydantionamino acid standards. Amino acid sequence analysis demonstrated that the peptide was blocked at the $\mathrm{N}$ terminus, and initial attempts to unblock the peptide were unsuccessful. Therefore, the glass fiber filter containing the reduced and alkylated peptide was placed back into a sequencer reaction cartridge, $15 \mu \mathrm{l}$ of $1 \mathrm{~mm}$ cyanogen bromide in $70 \%$ formic acid was added, and the filter containing the peptide was incubated in the sequencer for $2 \mathrm{hr}$ at $70^{\circ} \mathrm{C}$ under argon. The filter was dried with argon and then sequenced using normal pulsed liquid chemistry. Microsequence analysis revealed a partial 34-residue sequence corresponding to residues $7-40$ The partial sequence indicated a Pro residue at position 1 of the 34-residue sequence, suggesting that an Asp-Pro bond was cleaved by the formic acid treatment. This was confirmed by incubation with $70 \%$ formic acid alone at $21^{\circ} \mathrm{C}$, followed by microsequence analysis, which generated an identical sequence for the first 10 cycles. Formic acid cleavage of the Asp ${ }^{6}$-Pro 7 bond (and $\mathrm{Asp}^{41}$-Pro ${ }^{42}$ bond; see below) presumably generated a 35 residue peptide (residue $7-41$ ). To extend these data, fraction 1 was digested with endoproteinase Glu-C, and the resulting peptides were purified by RP-HPLC. Microsequence analysis of one peptide (residues $30-43$ ) extended the $\mathrm{C}$-terminal sequence by an additional three residues. Two tryptic peptides representing the $\mathrm{N}$ terminus (residues 1-12) and middle region (residues 13-38) of reduced and alkylated L-EGF were also characterized. The N-terminal tryptic peptide (residues 1-12) was treated with PGAP, and Edman degradation determined the sequence of residues 2-11. Matrix-assisted laser desorption/ionization time of flight mass spectrometry (MALDI-TOF MS), electrospray mass spectrometry (ES-MS) and ES collisionally induced dissociation (ES-CID) determined the identity of residue 1 of the N-terminal peptide (residues 1-12). Edman degradation confirmed the sequence of the second tryptic peptide (residues 13-38).

Reduction and alkylation of L-EGF. L-EGF peptide was denatured, reduced, and cysteines alkylated with 4-vinylpyridine (Hawke and Yuan, 1987; Coligan et al., 1996). One microgram of peptide was dissolved in 17.5 $\mu \mathrm{l}$ of denaturing buffer $(0.25 \mathrm{M}$ Tris-HCl, $1.0 \mathrm{~mm}$ EDTA, and $6.0 \mathrm{M}$ guanidine-HCl, pH 8.5), and $2.5 \mu \mathrm{l}$ of $10 \%$ 2-mercaptoethanol (Aldrich, Milwaukee, WI) was added. After $2.5 \mathrm{hr}$ at room temperature, $2 \mu \mathrm{l}$ of neat 4-vinylpyridine (Aldrich) was added. After an additional $2 \mathrm{hr}$ at room temperature, the solution was taken to dryness under vacuum with a SpeedVac concentrator (Savant Instruments, Inc., Hicksville, NY). The residue was dissolved in $25 \mu \mathrm{l}$ of $1 \% \mathrm{TFA}$ and desalted on a Hewlet Packard HP 1090 Liquid Chromatographic System using a $2.1 \times 30 \mathrm{~mm}, 5$ $\mu \mathrm{m} \mathrm{C18}$ column. The gradient solvents were aqueous $0.1 \%$ TFA (solvent A) and ACN/water/TFA, 80:20:0.01 (solvent B). After injection of the 25 $\mu$ sample and washing with $100 \% \mathrm{~A}$, the column was developed with a linear gradient of $100 \% \mathrm{~A}$ to $25 \% \mathrm{~A} / 75 \% \mathrm{~B}$ over $30 \mathrm{~min}$ at $0.175 \mathrm{ml} / \mathrm{min}$.
The fraction containing the salt-free alkylated peptide was taken to dryness in the vacuum concentrator and stored dry at $4^{\circ} \mathrm{C}$. The peptide was characterized by MALDI-TOF MS and ES-MS, and the reduced and alkylated peptide was found to have gained $630 \mathrm{Da}$, indicating that six cysteines had been alkylated (each pyridylethyl substitution adds $105 \mathrm{Da}$ ).

Reduction of L-EGF without alkylation. L-EGF peptide was denatured, reduced, and purified following the above procedure but without alkylation. The reduced peptide was characterized by MALDI-TOF MS and found to have gained $6 \mathrm{Da}$, indicating that three disulfide bonds had been reduced.

Endoproteinase Glu-C digestion of alkylated L-EGF peptide. An aliquot of reduced and alkylated L-EGF was digested with sequencing grade Glu-C (Boehringer Mannheim, Indianapolis, IN) by established procedures (Coligan et al., 1996). The resulting peptides were purified by C18 RP-HPLC $(4.6 \times 250 \mathrm{~mm}$; Vydac) using a gradient of $0.1 \%$ TFA and $100 \% \mathrm{ACN}$ containing $0.1 \%$ TFA and lyophilized, and the C-terminal Glu-C peptide (residues 30-43) was subjected to Edman microsequence analysis.

Trypsin digestion of the alkylated L-EGF peptide. One microgram of alkylated peptide was dissolved in $50 \mu \mathrm{l}$ of $0.1 \mathrm{M}$ ammonium bicarbonate, $0.025 \mu \mathrm{g}$ of $N$-tosyl-phenylalanine chloromethyl ketone-treated trypsin (Worthington, Freehold, NJ) was added, and the digestion reaction was incubated at $37^{\circ} \mathrm{C}$. The reaction was followed by MALDI-TOF MS and was complete after $2 \mathrm{hr}$. After the addition of $1 \mu \mathrm{l}$ neat TFA, the reaction was fractionated by C18 RP-HPLC $(2.1 \times 30 \mathrm{~mm}$ column; PE/Applied Biosystems) using a 15 min linear gradient of $0-75 \%$ ACN containing $0.1 \%$ TFA at $0.3 \mathrm{ml} / \mathrm{min}$ and monitored at $214 \mathrm{~nm}$. Alternatively, the reaction was fractionated by C18 RP-HPLC $(2.1 \times 150 \mathrm{~mm}$ column, $5 \mu \mathrm{m}$; Vydac) using a linear gradient of $0-60 \%$ ACN containing $0.1 \%$ TFA. Fractions were assayed for the desired alkylated peptide by MALDI-TOF MS. Two peptides were obtained representing the $\mathrm{N}$ terminus (residues 1-12) and middle (residues 13-38) portions of the L-EGF peptide. Appropriate fractions were pooled, taken to dryness in the vacuum concentrator, dissolved in $50 \%$ methanol/water containing $5 \%$ acetic acid, and further analyzed by ES-MS, ES-CID (residues 1-12), MALDI-TOF MS, and Edman degradation.

Pyroglutamate aminopeptidase digestion of alkylated $N$-terminal tryptic peptide (residues 1-12). PGAP (Boehringer Mannheim) digestion of the N-terminal tryptic peptide (residues 1-12) was performed in $100 \mathrm{~mm}$ potassium phosphate, $10 \mathrm{~mm}$ EDTA, $5 \mathrm{~mm}$ dithioerythritol, and $5 \%$ glycerol, $\mathrm{pH}$ 8.0. A ratio of $1 \mathrm{U}$ of enzyme/mg of peptide was used, and the mixture was incubated at $37^{\circ} \mathrm{C}$ overnight. The resulting peptide from the above digests was desalted using a C18 ZipTip pipette tip (Millipore, Danvers, MA). Aliquots of the desalted sample were taken for MALDITOF MS and Edman degradation.

Mass spectrometry. ES-MS was performed in a Perkin-Elmer Sciex API III triple-quadruple mass spectrometer (PE/Sciex, Thornfill, Ontario, Canada). When desalting was required, a liquid chromatograph (PE/Applied Biosystems model 140A) fitted with two $10 \mathrm{ml}$ syringe cylinders was used in series with the API III mass spectrometer. Desalting was performed on an Aquapore Butyl C4 column $(2.1 \times 30 \mathrm{~mm}, 7 \mu \mathrm{m}$; PE/Applied Biosystems) with a gradient of $2-70 \%$ ACN containing $0.05 \%$ TFA in $20 \mathrm{~min}$. MALDI-TOF MS was performed in a PE/PerSeptive Voyager-DE (PE/ PerSeptive BioSystems, Framingham, MA) using $\alpha$-cyano-4-hydroxycinnamic acid (Aldrich) for a matrix. The matrix-to-analyte ratio was 1000:1 and the "dried drop technique" was used in spotting the sample plate.

Cloning of L-EGF. Based on the L-EGF amino acid sequence, two degenerate sense oligonucleotides, L-EGF-S1 (5'-agaagcttggngcnaa $(\mathrm{t} /$ c) $\operatorname{tg}(\mathrm{t} / \mathrm{c})$ at $\left.(\mathrm{t} / \mathrm{c} / \mathrm{a}) \mathrm{gcnta}(\mathrm{t} / \mathrm{c}) \mathrm{gg}-3^{\prime}\right)$ and L-EGF-S2 (5'-agaagcttgcnat $(\mathrm{t} / \mathrm{c} /$ a) $\left.\operatorname{tg}(\mathrm{t} / \mathrm{c}) \mathrm{ga}(\mathrm{a} / \mathrm{g}) \operatorname{tg}(\mathrm{t} / \mathrm{c}) \operatorname{ccntt}(\mathrm{t} / \mathrm{c}) \mathrm{gg}-3^{\prime}\right)$, were designed and used to PCRamplify a $L-E G F$ cDNA fragment from an albumen gland-specific $\lambda$ ZAPII cDNA library. These primers were used in a nested PCR strategy in combination with primers directed against either the right $\lambda$ arm (EV2, $5^{\prime}$-cgccagggtttcccagtcacgac-3'; and T77, 5' -gcgtaatacgactcactatagggcga- $\left.3^{\prime}\right)$ or the left $\lambda$ arm (EV3, 5'-agcgataacaatttcacacagga-3'; and T33, 5' gcgcaattaaccctcactaaagg- $\left.3^{\prime}\right)$. The L-EGF primers contained at the $5^{\prime}$ end a recognition sequence for the restriction endonuclease HindIII. PCR was performed in a $50 \mu \mathrm{l}$ solution containing $\sim 10^{8} \mathrm{pfu}$ of phenol-extracted and ethanol-precipitated library DNA, $200 \mu \mathrm{M}$ each of the four deoxynucleotides, 50 pmol of L-EGF-s1, 12.5 pmol of EV2 or EV3, $20 \mathrm{~mm}$ Tris-HCl, $\mathrm{pH} 8.4,50 \mathrm{~mm} \mathrm{KCl}, 3 \mathrm{mM} \mathrm{MgCl}_{2}$, and $0.5 \mathrm{U}$ of $\mathrm{Taq}$ DNA polymerase (Goldstar). The PCR mixture was incubated in a DNA thermal cycler (Perkin-Elmer Cetus, Norwalk CT) for 42 cycles of $15 \mathrm{sec}$ at $94^{\circ} \mathrm{C}, 30 \mathrm{sec}$ at $46^{\circ} \mathrm{C}$, and $3 \mathrm{~min}$ at $72^{\circ} \mathrm{C}$. Of this PCR mixture, $1 \mu \mathrm{l}$ was reamplified for 35 cycles under the same conditions, now using primers L-EGF-s 2 in combination with T77 or T33. Amplified cDNA fragments were digested with EcoRI and HindIII, separated on agarose gel, cloned into pBluescript $\mathrm{KS}(+)$, and sequenced using an ABI 310 automated sequencer and the ABI PRISM Dye Terminator Cycle Sequencing kit (Perkin-Elmer Cetus). The cloned 300 bp $L-E G F$ cDNA fragment was labeled with $\left[\alpha_{-}{ }^{32} \mathrm{P}\right] \mathrm{dATP}$ by random priming and used as a probe to screen $\sim 100,000$ recombinant clones of the albumen gland cDNA library. The clones were plated, absorbed to replica nylon filters (Boehringer Mannheim), prehybridized at $65^{\circ} \mathrm{C}$ for $16 \mathrm{hr}$, and hybridized at $65^{\circ} \mathrm{C}$ for $60 \mathrm{hr}$. The prehybridization and hybridization solutions contained $6 \times$ SSC $(1 \times$ SSC: $150 \mathrm{~mm} \mathrm{NaCl}$ and 15 mM sodium citrate, $\mathrm{pH} 7.4$ ), $5 \times$ Denhardt's solution, $0.1 \%$ SDS, and 100 $\mu \mathrm{g} / \mathrm{ml}$ salmon sperm DNA. The filters were washed two times in $1 \times$ 
$\mathrm{SSC} / 0.1 \%$ SDS at $65^{\circ} \mathrm{C}$ for $15 \mathrm{~min}$, and hybridization signals were visualized using a GS-525 Molecular Imager System and Multi-Analyst 1.0 imaging software (both from Bio-Rad, Hercules, CA). Positive clones were isolated, and the insert-containing pBluescript phagemid (pBS-L-EGF) was rescued by in vivo excision and sequenced on both strands using vector-based primers and internal primers.

CNS organ culture. Adult Lymnaea CNS were dissected, washed $30 \mathrm{~min}$ in antibiotic saline (in mM: $51.3 \mathrm{NaCl}, 1.7 \mathrm{KCl}, 4.1 \mathrm{CaCl}_{2}, 1.5 \mathrm{MgCl}_{2}$, and 5 HEPES, pH 7.9) containing $150 \mu \mathrm{g} / \mathrm{ml}$ gentamicin (Sigma, St. Louis, MO), and cultured for $24 \mathrm{hr}$ in a modified Leibovitz L-15 defined medium (DM) (special order; Life Technologies, Rockville, MD) (Ridgway et al., 1991).

Northern blot analysis. Total RNA was isolated from albumen glands, acutely dissected adult CNS, and cultured adult CNS, using the guanidine isothiocyanate method (Chomczynski and Sacchi, 1987), and 15-20 $\mu \mathrm{g}$ of RNA was glyoxylated, fractionated on a $1.2 \%$ agarose gel, and transferred to a charged nylon membrane (Boehringer Mannheim). After prehybridization for $4 \mathrm{hr}$, the filter was hybridized at $65^{\circ} \mathrm{C}$ for $16 \mathrm{hr}$ with a full-length $\left[\alpha^{-32} \mathrm{P}\right] \mathrm{dATP}-$ labeled $L-E G F$ cDNA probe (specific activity, $>10^{8} \mathrm{dpm} /$ $\mu \mathrm{g}$ ) and washed in $0.2 \times \mathrm{SSC}, 0.1 \%$ SDS at $65^{\circ} \mathrm{C}$ for $30 \mathrm{~min}$, and hybridization signals were visualized using a GS-252 Molecular Imager System and Multi-Analyst 1.0 imaging software.

Reverse transcription-PCR. Total RNA was isolated from cultured adult CNS, acutely dissected adult CNS (from animals 10 weeks of age; shell length of 20-25 mm), acutely dissected juvenile CNS (from animals 3-4 weeks of age; shell length of $8-10 \mathrm{~mm}$ ), albumen glands as above, or egg masses at various developmental stages. In each case, 1-2 $\mu \mathrm{g}$ of RNA was reverse transcribed into oligo-dT 17 -primed cDNA using $200 \mathrm{U}$ of M-MLV reverse transcriptase (SuperScript II; Life Technologies). A 256 bp L-EGF cDNA fragment was amplified using primers L-EGF-S3 (5'-tggtgc gaattgtattgcctatgg- $\left.3^{\prime}\right)$ and L-EGF-AS1 (5'-ctttacaagttcataaccttatagtc- $\left.3^{\prime}\right)$. As positive controls for the cDNA synthesis, Lymnaea fructose 1,6biphosphate aldolase cDNA was amplified using primers Lald-6 $\left(5^{\prime}\right.$-gctggtcaaggatgcccc-3'; sense) and Lald-4 (5'-tagcttgtagagctcggccat-3'; antisense) (Van Kesteren et al., 1998), or Lymnaea tubulin cDNA was amplified using primers Ltub-s1 (5'-aggcggaatccaacatgaac- $\left.3^{\prime}\right)$ and Ltubas1 $\left(5^{\prime}\right.$-cccctcagcttcttcctcatc- $\left.3^{\prime}\right)$. PCR reactions were performed as described above. Thirty cycles (egg mass cDNA) or forty cycles (all other templates) were performed for $30 \mathrm{sec}$ at $94^{\circ} \mathrm{C}, 30 \mathrm{sec}$ at $58^{\circ} \mathrm{C}$, and $30 \mathrm{sec}$ at $72^{\circ} \mathrm{C}$. Twenty microliters of the PCR mixtures were separated on a $2 \%$ agarose gel and photographed.

Neuron isolation and outgrowth assays. Identified neurons were isolated from the CNS of adult Lymnaea (10-14 weeks of age; shell length of 20-25 $\mathrm{mm})$. Individual neurons were isolated according to the procedure described by Wildering et al. (1998). Neurons were cultured in DM, DM plus L-EGF, DM plus hEGF, or Lymnaea brain conditioned medium (CM) (Ridgway et al., 1991). Purified and lyophilized L-EGF or recombinant hEGF (PreproTech EC, Rocky Hill, NJ; gift of Dr. S. Weiss, University of Calgary, Calgary, Canada) were dissolved in DM to a final concentration in the plate of $100 \mathrm{~nm}$ (unless otherwise indicated). The protein kinase inhibitors K-252a (Kamiya, Seattle, WA) and PD153035 (gift of Dr. M. Hollenberg, University of Calgary; or supplied by CalbiochemNovabiochem, San Diego, CA) were dissolved in DMSO before addition to the culture medium. The final DMSO concentrations in the plate were 0.02 and $0.1 \% \mathrm{v} / \mathrm{v}$ for $\mathrm{K}-252 \mathrm{a}$ and PD153035, respectively. Control plates contained the same concentration of DMSO, and all reagents were added before the isolation procedure. Neurons were plated in specially prepared polystyrene culture dishes (Falcon \#3001; Becton Dickinson Labware, Franklin Lakes, NJ) containing a poly-L-lysine-coated small-volume (150 $\mu l)$ center well (Wildering et al., 1998). To minimize evaporation from the center well, the outer part of the dish was also filled with DM without allowing contact between the inner and outer compartment. A variety of neurons were isolated and cultured for the outgrowth assays: right Parietal A cluster (RPA) and Pedal A cluster (PeA) motoneurons, the peptidergic neuron right Parietal Dorsal 2 (RPD2) and peptidergic neurons from the right Parietal B cluster (RPB), the dopaminergic interneuron right Pedal Dorsal 1 (RPeD1), and the identified neurons Visceral Dorsal 2 and 3 $(\mathrm{VD} 2 / 3)$. Neurons were considered to have extended neurites if they showed at least one primary neurite of more than one soma diameter in length with an active growth cone. Neurite outgrowth was scored $\sim 48 \mathrm{hr}$ after isolation, and all sessions included a control. Every outgrowth result of each experiment was derived from multiple isolation sessions. The identity of the dishes was unknown to the individuals involved in the plating as well as the scoring of outgrowth. The dose-response data regarding L-EGF-induced neurite outgrowth in RPA neurons were fitted with a nonlinear regression routine (Leverberg-Marquardt method) to a four-parameter logistic equation (i.e., sigmoidal dose-response curve with variable slope). The dose-response data regarding the inhibition of L-EGF-induced neurite outgrowth by the protein kinase inhibitor K-252a was analyzed by means of a $\chi^{2}$ test for trend. Effects of single doses of K-252a or PD153035 on CM-, L-EGF- and hEGF-induced neurite outgrowth were analyzed by a Fisher's exact test. The number of neurons $(n)$ given in the text or figure legends reflects the total, pooled number of neurons plated under that condition (i.e., the sum of multiple isolation sessions). The percentages of neurite outgrowth are presented with their $95 \%$ confidence intervals $\left(\mathrm{CI}_{95 \%}\right)$ of ratios as calculated from the $\mathrm{F}$
A

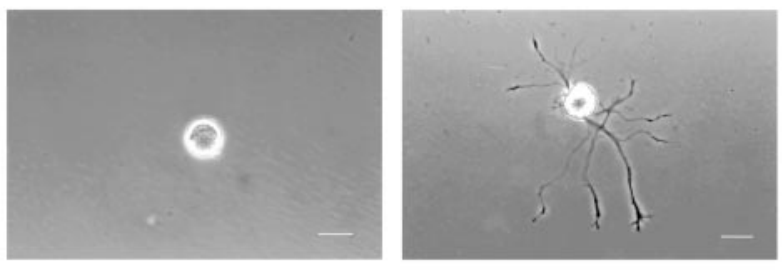

B

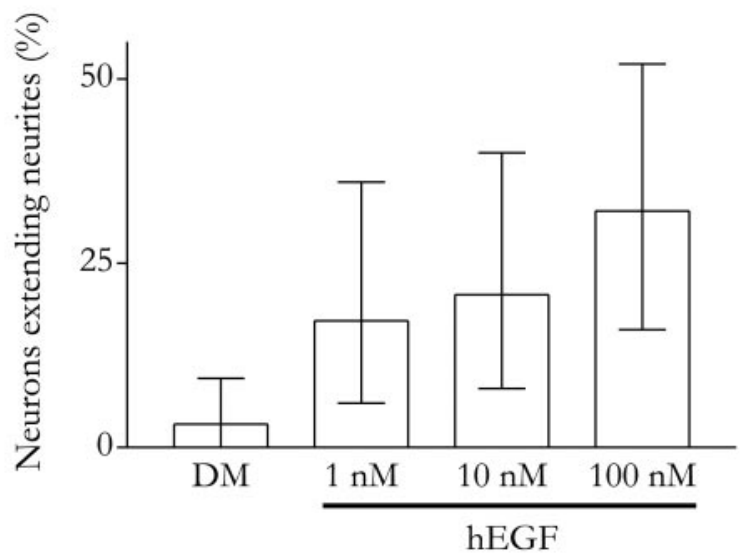

Figure 1. Human EGF induced neurite outgrowth in RPA motoneurons. $A$, Photomicrographs of RPA motoneurons cultured for $48 \mathrm{hr}$ in either DM (left panel) or DM plus $100 \mathrm{nM}$ hEGF (right panel). The addition of hEGF to the culture medium induced neurite outgrowth in this type of neuron. Scale bar, $50 \mu \mathrm{m}$. B, Different concentrations of hEGF induced neurite extension in RPA motoneurons after $48 \mathrm{hr}$ in culture. The percentages are presented with their $95 \%$ confidence intervals.

distribution according to Sachs (1982). The two-sided critical value of statistical significance was $p<0.05$.

\section{RESULTS}

\section{Human EGF promotes neurite outgrowth from molluscan neurons}

We tested the hypothesis that EGF can exert neurotrophic actions in adult Lymnaea neurons. To address this issue, we first assayed recombinant hEGF in our in vitro system. Previous studies showed that Lymnaea CM, murine $2.5 \mathrm{~S}$ nerve growth factor (NGF), and several extracellular matrix factors induce neurite outgrowth from RPA motoneurons in culture (Ridgway et al., 1991; Wildering et al., 1998). These neurons are readily isolated in large numbers and were used in our initial neurite outgrowth assays. RPA neurons were cultured in DM with the addition of $1(n=29), 10(n=29)$, or $100(n=28)$ nM hEGF (Fig. 1$)$. In general, RPA neurons did not show neurite extension when cultured in DM $(n=31)$ (Fig. $1 A$, left, $B$; also see Fig. 5). Addition of hEGF to the culture medium induced neurite outgrowth in a percentage of the RPA motoneurons (Fig. $1 A$, right). Concentrations of 1,10 , and $100 \mathrm{~nm}$ hEGF induced outgrowth in 17, 21, and $32 \%$ of RPA neurons, respectively (Fig. $1 B$ ). These data show that hEGF can act as a neurotrophic factor on adult Lymnaea motoneurons, suggesting the existence of an endogenous Lymnaea EGF homolog.

\section{Purification and characterization of Lymnaea EGF}

Mammalian EGF is known to be involved in the control of cell proliferation and differentiation during development (PlataSalamán, 1991; Gage et al., 1995; Weiss et al., 1996; Yamada et al., 
A

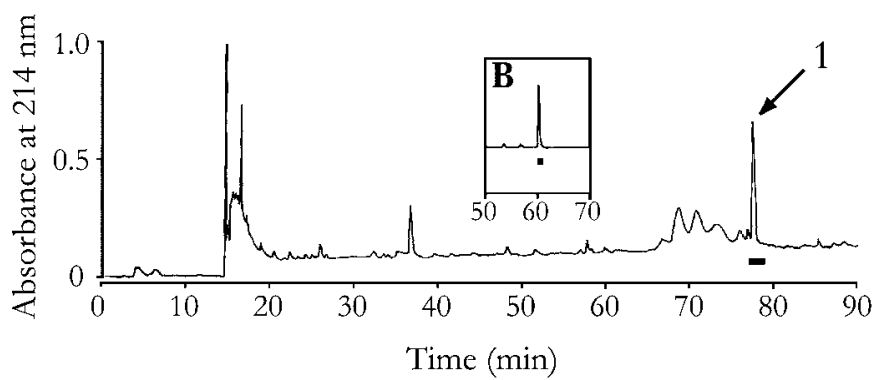

Figure 2. Purification of Lymnaea EGF. A, C18 RP-HPLC profile of an extract of 10 Lymnaea albumen glands that was fractionated using a gradient of $0.1 \%$ HFBA and ACN containing $0.1 \%$ HFBA. $B$, Fraction 1 in $A$ was reduced, alkylated, and purified using a gradient of $0.1 \%$ TFA and ACN containing $0.1 \%$ TFA. The absorbance profile suggested that the peptide had been purified to homogeneity, which was confirmed by subsequent microsequence and mass spectrometric analyses (Table 2). Fractions containing L-EGF are indicated by solid bars.

1997; Temple and Alvarez-Buylla, 1999). Thus, a potential source of Lymnaea EGF are the glands that secrete fluids surrounding the fertilized oocytes before they are packaged into egg masses (e.g., albumen gland, oothecal gland; Joosse and Geraerts, 1983). We prepared protein extracts from albumen glands and separated these using RP-HPLC. A representative RP-HPLC elution is shown in Figure $2 A$. A major absorbance peak corresponding to fraction 1 was reduced and alkylated and then further purified by RP-HPLC using a different counterion (Fig. 2B). The amino acid composition analysis indicated that purified fraction 1 (Fig. $2 B$ ) contained a peptide that was 40-43 residues in length (Table 1). Microsequence analysis and mass spectrometry confirmed a length of 43 residues and demonstrated that this peptide is $35 \%$ identical $(47 \%$ with conserved substitutions) with mouse EGF, including the EGFlike six cysteine residues and three $\mathrm{C}$-terminal residues (Table 2, Fig. $3 A$ ). Therefore, we named this peptide L-EGF.

The observed mass of native L-EGF agrees with that calculated for the determined sequence of the native structure containing three disulfide bonds (Table 2), thus precluding any additional residues or additional post-translational modifications. A sequence comparison of L-EGF with other members of the EGF family shows a strict conservation of all six cysteine residues (positions 8 , 13, 19, 28, 30, and 39), as well as the three characteristic EGF-like residues in the $\mathrm{C}$-terminal region $\left(\mathrm{Tyr}^{34}, \mathrm{Gly}^{36}\right.$, and $\mathrm{Arg}^{38}$ ) (Fig. 3A) (Carpenter and Cohen, 1990). The spacing between the firstsecond and third-fourth cysteine residues differs from the vertebrate EGF family members but is identical to the EGF-like motifs that are found in molecules such as Notch and Delta (Fig. $3 A$ ).

\section{Cloning and structural characteristics of L-EGF}

PCR on independent fractions of an albumen gland-specific cDNA library with degenerate oligonucleotide primers in combination with vector-based primers resulted in the identification of a single $300 \mathrm{bp}$ PCR product in each fraction. Nucleotide sequencing of this product revealed that it encoded the C-terminal region of $L-E G F$, as predicted by the amino acid sequence data, followed by a stop codon, a short $3^{\prime}$ untranslated region of $216 \mathrm{bp}$, and a poly $\left(\mathrm{A}^{+}\right)$tail. Using this cDNA fragment as a probe, the full-length $L-E G F$ cDNA was isolated from one of the library fractions and completely sequenced on both strands. The full-length $L-E G F$ cDNA is 451 bp in length and contains a single open reading frame encoding a 64 amino acid protein, preceded by several in-frame stop codons, indicating that the open reading frame is complete at the $5^{\prime}$ end (Fig. 3B).

The predicted L-EGF precursor protein consists of a 21 amino acid signal peptide, which is predicted to be cleaved after $\mathrm{Ala}^{-1}$ (Von Heijne, 1983). The remaining EGF domain is 43 amino acids
Table 1. Amino acid composition of Lymnaea EGF

Residues/mol peptide

\begin{tabular}{llc}
\cline { 2 - 3 } Amino acid & Composition & Sequence $^{a}$ \\
\hline Aspartic acid & $5.1(5)$ & 5 \\
Glutamic acid & $4.1(4)$ & 5 \\
Serine & $3.0(3)$ & 3 \\
Glycine & $5.6(5-6)$ & 6 \\
Arginine & $2.0(2)$ & 2 \\
Threonine & $1.0(1)$ & 1 \\
Alanine & $3.3(3)$ & 3 \\
Proline & $3.1(3)$ & 3 \\
Tyrosine & $3.3(3)$ & 3 \\
Valine & $0.8(1)$ & 1 \\
Cysteine & $5.5(5-6)$ & 6 \\
Isoleucine & $4.5(4-5)$ & 4 \\
Phenylalanine & $1.1(1)$ & 1 \\
Total & $40-43$ & 43 \\
\hline
\end{tabular}

${ }^{a}$ Residues quantitated by HPLC.

in length and is identical to the amino acid sequence of the purified L-EGF peptide (compare Fig. $3 B$ with Fig. $3 A$ and Table 2). Comparison of the $L-E G F$ precursor with other vertebrate and invertebrate members of the EGF family of growth factor precursors (e.g., hEGF, TGF $\alpha$, amphiregulin, and spitz) and precursors with EGF motifs not belonging to the EGF family, such as Notch 3 and Delta 1 , shows that the $L-E G F$ precursor is surprisingly simple (Fig. $3 C$ ). Whereas these other precursors are large and complex multiple-domain proteins, most of which have a transmembrane domain, the L-EGF precursor contains only a signal peptide and a single copy of L-EGF. Conspicuously, the $L-E G F$ precursor lacks a transmembrane domain, setting it apart from all other members of the EGF family. The presence of a signal peptide together with the absence of a transmembrane domain strongly suggest that L-EGF is a secreted peptide.

\section{L-EGF expression in ovo, albumen gland, juvenile, and organ-cultured adult CNS}

Northern blot hybridization using the full-length $L-E G F$ cDNA as a probe revealed a very abundant transcript of $\sim 450 \mathrm{bp}$ in the albumen gland, but no L-EGF transcript was detected in the adult CNS either when acutely dissected or after organ culture for $24 \mathrm{hr}$ (Fig. 4A). The size of the transcript detected in albumen glands corresponds well with the size of the cloned $L-E G F$ cDNA, confirming that this clone is indeed full-length.

Because the $L-E G F$ mRNA might be expressed in the CNS at levels below the detection limit of a Northern blot hybridization, we extended our expression studies to reverse transcription (RT)-PCR analysis of cDNA derived from albumen gland, juvenile CNS, acutely dissected adult CNS, and organ-cultured adult CNS (Fig. $4 B)$ (see Material and Methods). In agreement with the Northern blot hybridization, $L-E G F$ cDNA could be amplified from albumen glands but not from acutely dissected adult CNS. RT-PCR revealed, however, abundant expression of $L-E G F$ mRNA in juvenile CNS and an upregulation of $L-E G F$ mRNA levels in the organcultured adult CNS (Fig. 4B, top panel). As a positive template control, Lymnaea fructose 1,6-biphosphate aldolase was amplified with consistency from all cDNA preparations (Fig. 4B, bottom panel).

The expression of L-EGF in the albumen gland and the developing juvenile CNS suggests a role for L-EGF during embryonic development. Therefore, we next examined the expression of $L-E G F$ mRNA in egg masses at different times from day 3 after deposition [embryonic day 3 (E3)] to the day of hatching (E13). Expression of $L-E G F$ mRNA could be detected in all stages of in 
Table 2. Chemical and mass spectrometric sequence analysis of Lymnaea stagnalis EGF

\begin{tabular}{|c|c|c|c|c|c|}
\hline Treatment & Fragment & Sequence & $\begin{array}{l}\text { Calculated } \\
\text { observations }\end{array}$ & $\begin{array}{l}\text { Mass Da } \\
\text { (average) }\end{array}$ & Procedures \\
\hline \multirow[t]{2}{*}{ None } & $(1-43)$ & & $4541.0^{a}$ & 4540.8 & ES-MS \\
\hline & & & & 4540.9 & MALDI \\
\hline Reduced & $(1-43)$ & & 4547.0 & 4546.9 & MALDI \\
\hline Red. \& Alk. & $(1-43)$ & & 5177.9 & 5177.5 & MALDI \\
\hline Red. \& Alk./70\% formic & $(7-41)$ & PXQIVRXSYGANXIAYGDTAIXEXPFGYSGIRXQ & & & Edman \\
\hline \multirow[t]{4}{*}{ Tr. of Red. \& Alk. } & $(1-12)$ & & 1404.5 & 1404.7 & MALDI \\
\hline & & & & 1403.8 & ES-MS \\
\hline & $(1-12)$ & $<Q G D G E D P X Q I V R$ & & & ES-CID \\
\hline & $(13-38)$ & XSYGANXIAYGDTAIXEXPFGYSGI & 3155.7 & 3155.4 & Edman, MALDI \\
\hline PGAP of $(1-12)$ & $(2-12)$ & GDGEDPXQIV & 1293.4 & 1293.6 & Edman, MALDI \\
\hline Red. \& Alk./Glu-C & $(30-43)$ & XPFGYSGIRXQDPS & & & Edman \\
\hline \multirow[t]{3}{*}{ Sequence } & $(1-43)$ & $<Q G D G E D P C Q I V R C S Y G A N C I A Y G D T A I C E C P F G Y S G I R C Q D P S$ & & & \\
\hline & & $\mid \begin{array}{llll}\mid & \mid & \mid\end{array}$ & & & \\
\hline & & 40 & & & \\
\hline
\end{tabular}

$\langle$ Q, Pyrrolidone carboylic acid; Red. \& Alk., reduction and alkylation; X, pyridylethyl cysteine; Tr, trypsin; Glu-C, endoproteinase Glu-C.

${ }^{a}$ Calculated as oxidized peptide; therefore, three disulfide bonds.

A

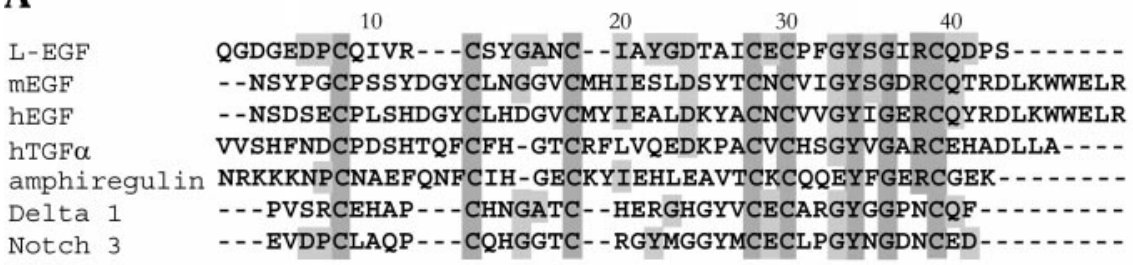

B

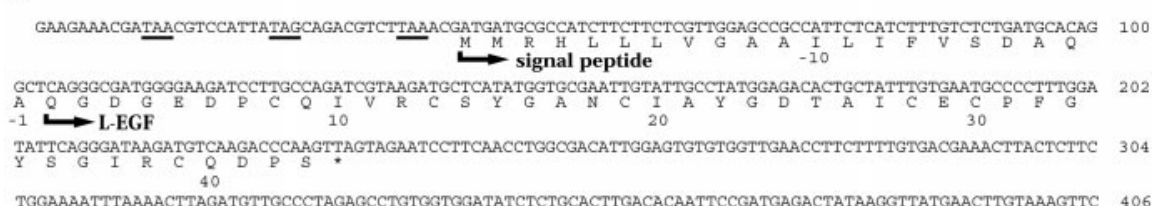

TGGAAAATTTAAAACTTAGATGTTGCCCTAGAGCCTGTGGTGGATATCTCTGCACTTGACACAATTCCGATGAGACTATAAGGTTATGAACTTGTAAAGTTC 406 GGCTGTTAAAAATATCATAAAAAAATAAACAGTTGTTCTTGAACT-DO1Y (A)
Figure 3. cDNA and deduced amino acid sequence of $L-E G F$ and alignment of L-EGF with vertebrate and invertebrate EGF-related proteins and precursor molecules. $A$, Amino acid sequence alignment of L-EGF and EGF-like motifs from mouse EGF ( $m E G F$ ) (GenBank accession number GI494001; Savage et al., 1972), hEGF (GenBank accession number NP 001954; Bell et al., 1986), human transforming growth factor $\alpha(h T G F \alpha)$ (GenBank accession number AAA61158; Derynck et al., 1984), human amphiregulin (amphiregulin) (GenBank accession number NP 001648; Plowman et al., 1990), human Delta-1 (Delta 1) (GenBank accession number NP 005609; unpublished), and human Notch 3 (Notch 3) (GenBank accession number NP 000426; Lewis, 1996). Note the conservation of all six cysteine residues (positions $8,13,19,28,30$, and 39), as well as the characteristic EGF-like residues in the $\mathrm{C}$ terminal, i.e., $\mathrm{Tyr}^{34}$, Gly ${ }^{36}$, and $\mathrm{Arg}^{38}$. B, cDNA sequence and deduced amino acid sequence of $L-E G F$. Nucleotide positions are numbered at the right; amino acid positions are numbered below the amino acid sequence. The first amino acid of the signal sequence and of the L-EGF domain are indicated by arrows. In frame, stop codons in the $5^{\prime}$ untranslated region are underlined; asterisk denotes the stop codon; a putative polyadenylation signal in the $3^{\prime}$ untranslated region is in bold. $C$, Comparison of the L-EGF precursor molecule with other EGF(-like) precursor molecules, i.e., TGF $\alpha$, amphiregulin, Drosophila spitz, hEGF, Notch 3, and Delta 1. Gray blocks indicate EGF-like motifs; dotted blocks indicate non-EGF-like repeat motifs. SP, Signal peptide; TM, transmembrane domain. ovo development (Fig. 4C, top panel). As a positive template control, Lymnaea tubulin was amplified consistently from all cDNA preparations (Fig. 4C, bottom panel).

\section{L-EGF induces neurite outgrowth}

The upregulation of $L-E G F$ mRNA in axotomized adult CNS suggests a role for L-EGF in injury repair. Thus, we examined whether L-EGF has neurotrophic activity in Lymnaea. To this end, RPA motoneurons were cultured in DM containing L-EGF at concentrations ranging from $300 \mathrm{pM}$ to $1 \mu \mathrm{M}$ ( $n>25$ for each concentration) (Fig. 5). As a control, RPA neurons were cultured in DM only $(n=89)$. Our experiments showed that L-EGF induced neurite outgrowth from RPA neurons in a dose-dependent manner. The trophic activity of the peptide extended over a three log range of concentrations (Fig. 5). The threshold dose was $\sim 1 \mathrm{nM}$, whereas the response reached a plateau at $\sim 1 \mu \mathrm{M}$, with an $\mathrm{EC}_{50}$ of $22 \mathrm{nM}$ $\left(\mathrm{CI}_{95 \%}\right.$ of $\left.8.8-54 \mathrm{~nm}\right)$ (Fig. 5). In accord with previous studies, only a small percentage $(<5 \%)$ of the neurons cultured under control 


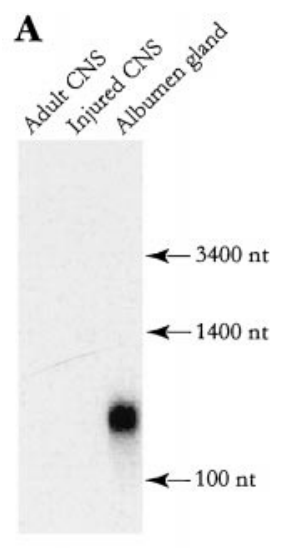

B

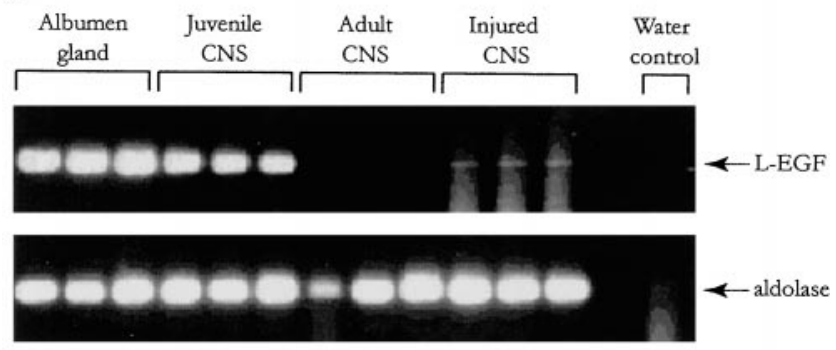

C E3 E4 E5 E6 E7 E8 E9 E10 E11 E13 contro
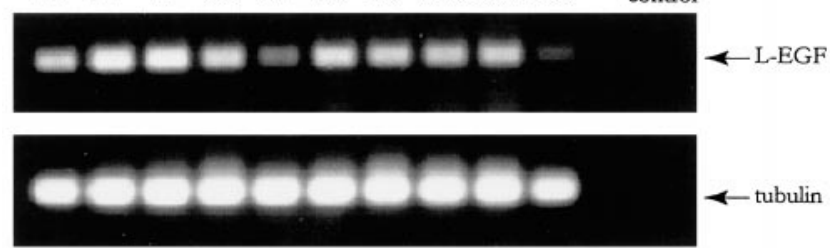

Figure 4. L-EGF expression in the developing and adult CNS. $A$, Northern blot hybridization of adult CNS, injured cultured adult CNS, and Lymnaea albumen gland show only transcript of a 450 nucleotides in the albumen gland. No $L-E G F$ mRNA was found in the acutely dissected or injured cultured adult CNS. B, RT-PCR analysis of expression of $L-E G F$ in the albumen gland, juvenile CNS, and injured cultured adult CNS. Acutely dissected adult CNS did not express $L-E G F$. Oligonucleotide primers against fructose 1,6-biphosphate aldolase generated a PCR product of the expected size in all tissues. PCR water controls are shown in the right lanes. $C$, RT-PCR analysis of expression of $L-E G F$ in developing Lymnaea embryos. L-EGF mRNA expression was observed in egg masses from $3 \mathrm{~d}$ after egg mass deposition (E3) up to hatching (E13). Oligonucleotide primers against Lymnaea tubulin generated a PCR product of the expected size in all tissues. PCR water controls are shown in the right lanes.

conditions (i.e., DM alone) exhibited neurite outgrowth (Ridgway et al., 1991; Wildering et al., 1998) (Figs. 1A,B, 5).

\section{Specificity of L-EGF-induced neurite outgrowth}

We expanded our study to ask whether L-EGF could induce outgrowth from neurons other than RPA motoneurons. To this end, we isolated and cultured a number of different types of identified neurons: another group of motoneurons (PeA neurons), two types of neurosecretory cells (RPB neurons and the unique cell designated as RPD2), and an interneuron (RPeD1, also known as the giant dopamine cell). We also examined a pair of identical neurons, VD2/3, which are of unknown function but whose morphology suggests a visceral function (Magoski and Bulloch, 1997). As a positive control, neurons were cultured in CM, which is a potent stimulator of neurite outgrowth in all types of Lymnaea

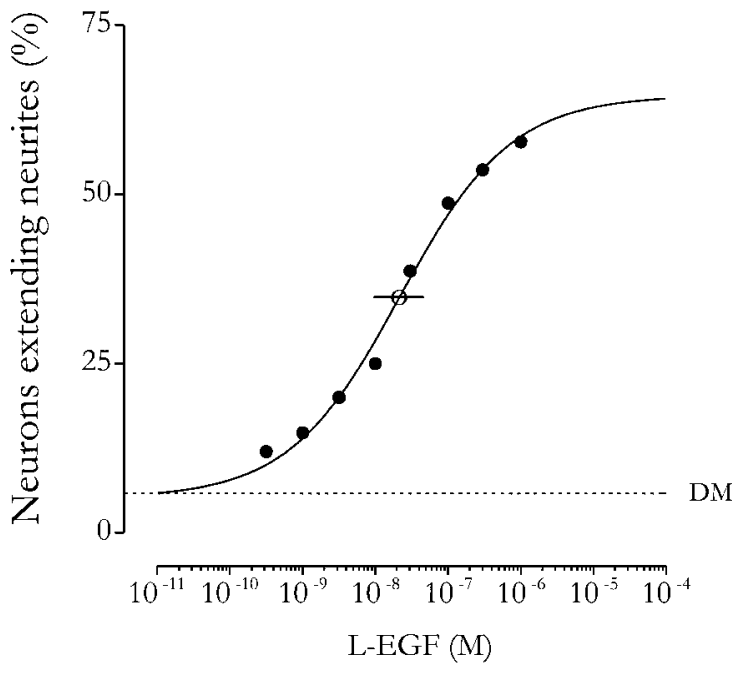

Figure 5. Dose-response curve of Lymnaea EGF. Neurite outgrowth in RPA neurons after $48 \mathrm{hr}$ in culture. The lowest concentration of L-EGF that induced neurite outgrowth was $\sim 1 \mathrm{nM}$, whereas maximal outgrowth was observed at $1 \mu \mathrm{M}$. The $\mathrm{EC}_{50}$ (open circle) as derived from the fitted model was $22 \mathrm{nM}$. The $95 \%$ confidence interval of the $\mathrm{EC}_{50}$ was $8.8-54 \mathrm{~nm}$ (horizontal bar). The number of neurons cultured per concentration was $>25$. The total number of neurons cultured in L-EGF was $>230$.

neurons tested to date (Ridgway et al., 1991). As expected, all of the six types of neurons tested in $\mathrm{CM}$ exhibited robust outgrowth after 1-2 d of culture (Fig. 6). The morphology of cells that responded to CM (Fig. 6A) was similar to previous studies (Ridgway et al., 1991; Wildering et al., 1998). In contrast, L-EGF induced neurite outgrowth in only three of the six cell types tested, these being the RPA and PeA motoneurons and the visceral neurons VD2/3 (Fig. 6). The appearance of the sprouted cells was strikingly different in L-EGF compared with CM but was similar to that observed in hEGF; the neurites were relatively thick and short, i.e., the axons often extended only a few soma diameters in length, even after extended culture periods (Figs. 1 $A, 6 A$ ). Despite these different morphological phenotypes, the percentage of cells that responded to L-EGF was not different from CM (Fig. 6B). The three cell types that did not respond to L-EGF (i.e., RPB, RPD2, and RPeD1) always remained spherical without any sign of process outgrowth (Fig. 6A).

\section{L-EGF signaling}

Given that EGF is known to signal via a tyrosine kinase receptor in vertebrate cells (Yamada et al., 1997), we assayed the effects of kinase inhibitors on L-EGF- and hEGF-evoked responses (Fig. 7). RPA motoneurons were cultured in the presence of either L-EGF $(100 \mathrm{nM})$ or hEGF (100 nM) with (experimental) or without (control) the addition of $\mathrm{K}-252 \mathrm{a}$, a broad-spectrum protein kinase inhibitor (Fig. 7A) (Kase et al., 1986, 1987; Ruegg and Burgess, 1989; Knüsel and Hefti, 1992). A similar percentage of the neurons cultured in the presence of L-EGF $(49 \%, n=47)$ (Figs. 5, 6) or hEGF (32\%, $n=38$ ) (Fig. 1B) exhibited neurite outgrowth (Fig. $7 A$ ). In the presence of the inhibitor, L-EGF-induced neurite outgrowth was significantly reduced in a dose-dependent manner

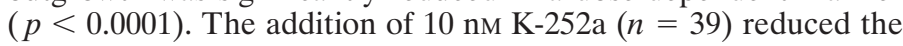
responsiveness of neurons to L-EGF. The addition of $100 \mathrm{~nm}$ K-252a completely blocked neurite outgrowth, and the neurons remained spherical in both L-EGF $(n=38)$ and hEGF $(n=46$, $p<0.0001$ ) (Fig. 7A).

Second, we tested the effects of PD153035, a tyrosine kinase inhibitor reported to be specific for the EGF receptor (EGFR) (Fry et al., 1994), on outgrowth induced by CM, 100 nM L-EGF, or 100 nM hEGF (Fig. 7B). Without inhibitor, 56, 43, and $38 \%$ of the neurons showed neurite outgrowth in CM $(n=50)$, L-EGF $(n=$ $84)$, or hEGF $(n=39)$, respectively (Fig. $7 B)$. Importantly, the addition of $100 \mathrm{~nm}$ PD153035 did not affect the outgrowth of RPA 
A

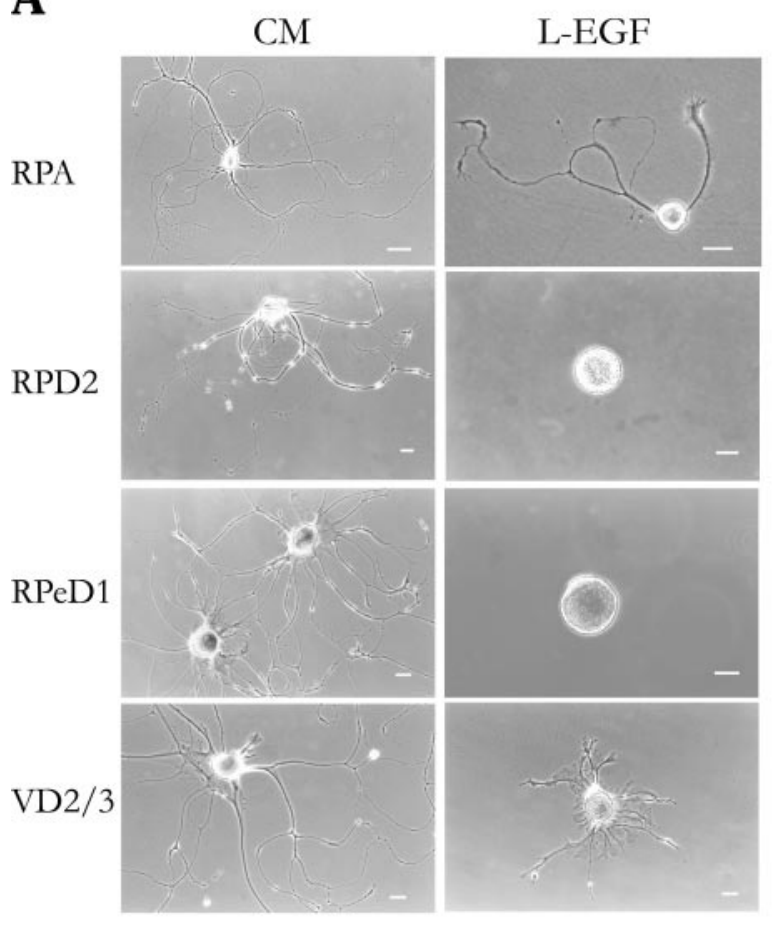

B

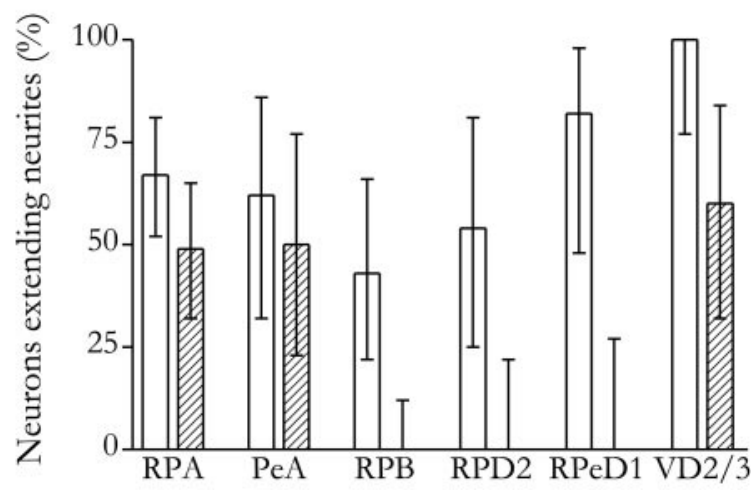

Figure 6. Specificity of L-EGF-induced neurite outgrowth. $A$, Photomicrographs of different types of neurons cultured for $48 \mathrm{hr}$ in either CM (left panels) or DM with $100 \mathrm{nM}$ L-EGF (right panels). RPA motoneurons, the neurosecretory neuron RPD2, the dopaminergic interneuron RPeD1, and the neurons VD2/3 developed multiple neurites when cultured in CM. In contrast, only RPA neurons and VD2/3 showed neurite outgrowth in the presence of $100 \mathrm{~nm}$ L-EGF. The neurons RPD2 and RPeD1 remained spherical. Scale bar, $50 \mu \mathrm{m}$. $B$, The percentage of neurons developing neurites after culturing for $48 \mathrm{hr}$ in either CM (open bars) or DM plus 100 nM L-EGF (hatched bars). The majority of RPA and PeA motoneurons $(n=46$ and 13, respectively), the neurosecretory RPB neurons $(n=21)$ and $\operatorname{RPD} 2(n=13)$, the interneuron RPeD1 $(n=11)$, and the identified VD2/3 $(n=14)$ showed neurite outgrowth in the presence of CM. When cultured in the presence of $100 \mathrm{~nm}$ L-EGF, only RPA $(n=39)$ and PeA $(n=14)$ motoneurons and VD2/3 $(n=15)$ extended neurites. The RPB neurons $(n=30)$ and the identified neurons RPD2 $(n=15)$ and RPeD1 $(n=12)$ always remained spherical in the presence of $100 \mathrm{~nm}$ L-EGF. The percentages are presented with their $95 \%$ confidence intervals.

neurons in CM $(n=48, p=0.69)$ (Fig. $7 B)$, indicating that the inhibitor had no nonspecific adverse effect on the cells. The presence of PD153035, however, significantly reduced the percentage of neurons extending neurites in L-EGF $(n=90, p<0.0005)$ (Fig. $7 B)$ and in hEGF $(n=46, p<0.025)$ (Fig. $7 B)$.
A

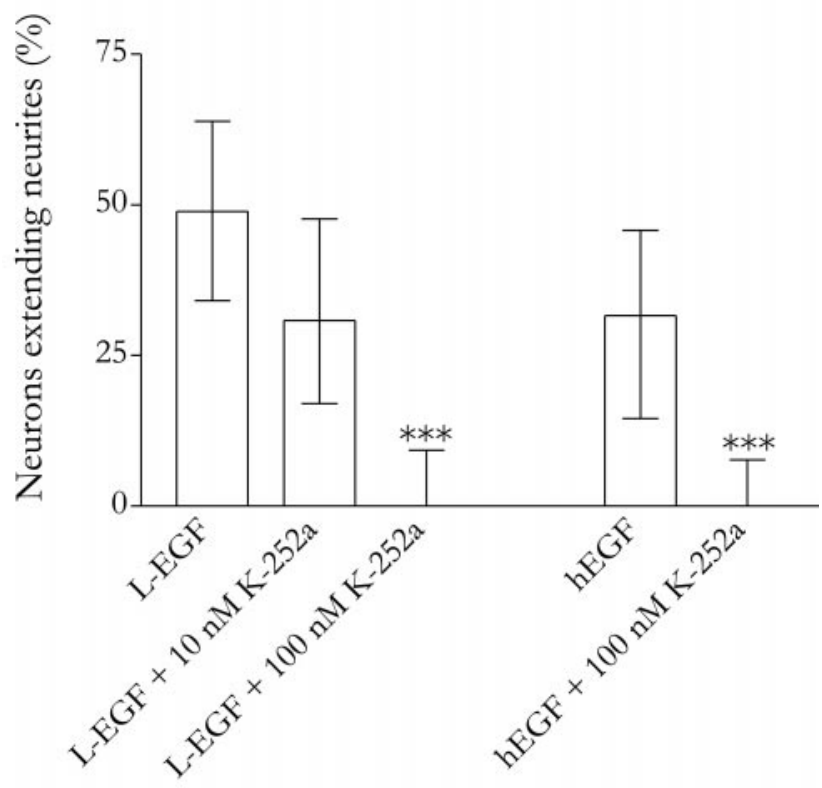

B

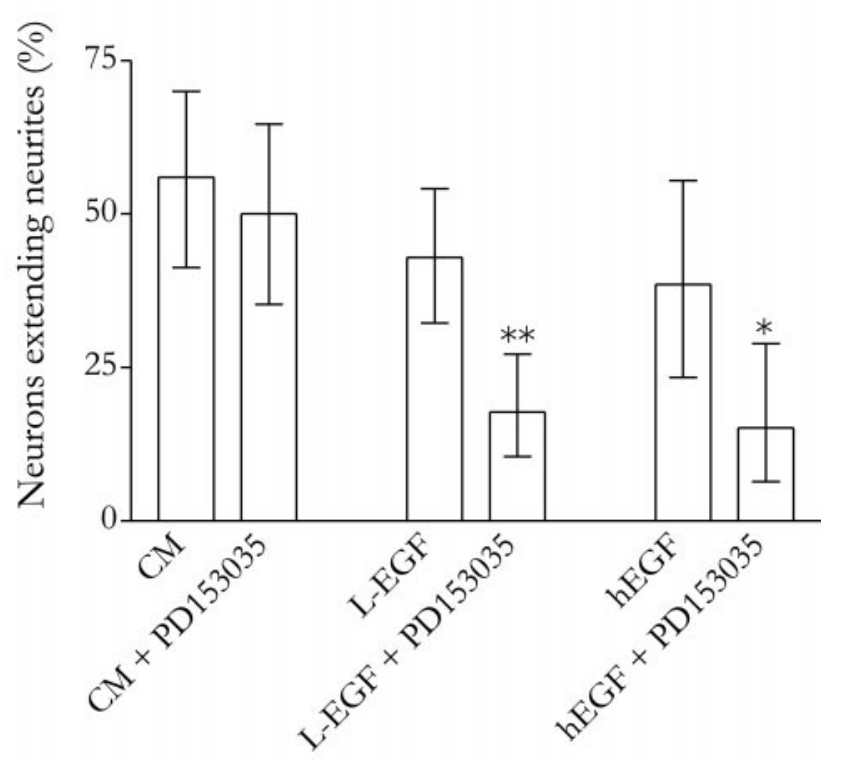

Figure 7. Receptor tyrosine kinase-mediated L-EGF signaling in RPA motoneurons. $A$, The protein kinase inhibitor K-252a significantly reduced L-EGF-induced neurite outgrowth in a dose-dependent manner $\left(\chi^{2}\right.$ test for trend) and hEGF-induced neurite outgrowth (Fisher's exact test). The percentages are presented with their $\mathrm{CI}_{95 \%}$. $B$, The specific EGFR tyrosine kinase inhibitor PD153035 (100 nM) significantly reduced L-EGF- and hEGF-induced neurite outgrowth (Fisher's exact test). In contrast, CMevoked neurite outgrowth was not affected by $100 \mathrm{~nm}$ PD153035 ( $p=0.69$; Fisher's exact test). The percentages are presented with their $95 \%$ confidence intervals. * $p<0.025 ; *^{*} p<0.0005 ; * * * p<0.0001$.

\section{DISCUSSION}

In this study, we purified and cloned a Lymnaea epidermal growth factor homolog (L-EGF) and characterized its neurotrophic actions. Expression patterns suggest that L-EGF has a developmental role in embryos and in the juvenile CNS and is involved in injury response of the adult CNS. The latter notion is supported by our 
finding that L-EGF evokes neurite outgrowth in some but not all identified adult neurons in vitro, suggesting differential neurotrophic actions.

\section{Molecular structure of L-EGF}

The L-EGF precursor is rather unique and surprisingly simple compared with the precursor of other EGF family members (e.g., $\mathrm{EGF}, \mathrm{TGF} \alpha$, amphiregulin, spitz, and gurken) and other proteins containing an EGF motif (e.g., Notch and Delta). The L-EGF precursor molecule contains only a signal peptide and a single copy of L-EGF and lacks a transmembrane domain. Whereas mammalian EGF precursors require proteolytic processing to release EGF, we predict that L-EGF is synthesized as a nonmembrane-bound peptide and subsequently secreted.

Importantly, the cDNA clone of $L-E G F$ predicts the same amino acid sequence as the purified peptide. Together, the purification and cloning data show that L-EGF has the typical arrangement of six cysteine residues and three characteristic amino acid residues in the C-terminal region $\left(\mathrm{Tyr}^{34}, \mathrm{Gly}^{36}\right.$, and $\mathrm{Arg}^{38}$ ) that are found in most EGF-related proteins (Carpenter and Cohen, 1990). The cysteine residues form three intramolecular disulfide bonds that are necessary for maintaining the biological activity of EGF (Taylor et al., 1972; Savage et al., 1973). Although our data do not support any assignment, the canonical EGF disulfide pattern would predict cystinyl bridges between positions 8 and 19, 13 and 28, and 30 and 39 (Table 2).

Whereas EGF itself has only been reported in mammals, EGFlike domains have been found in genes from a wide variety of organisms ranging from the protist Plasmodium falciparum (Kaslow et al., 1988) to invertebrate and vertebrate multizoa (Greenwald, 1990; Muskavitch and Hoffmann, 1990; Yamada et al., 1997). This suggests that the EGF motif has an ancient origin and is conserved in eukaryotes. Although the six cysteine residues are invariably present in all EGF-like domains, the spacing between the first two pairs of cysteine residues varies (Greenwald, 1990; Muskavitch and Hoffmann, 1990; Rutledge et al., 1992; Yamada et al., 1997; Van de Poll et al., 1998). L-EGF in this regard shares a higher similarity with the EGF-like repeats in proteins such as Notch and Delta than with EGF itself (Fig. 3A). It is suggested that size and composition of the cysteine loops are an important determinant of receptor binding by EGF (Van de Poll et al., 1998). However, although hEGF and L-EGF differ in their cysteine residue spacing, the fact that both peptides induced neurite outgrowth from Lymnaea neurons in vitro suggests that receptor-binding properties are conserved. This notion is supported by the observation that the neurotrophic effect of both L-EGF and hEGF could be inhibited by PD153035, a specific inhibitor of the EGFR (see Results and below, L-EGF signaling).

\section{Developmental significance of L-EGF}

Mammalian EGF is expressed in the developing and adult CNS (Rall et al., 1985; Schaudies et al., 1989; Lazar and Blum, 1992). In this study, we showed that L-EGF is synthesized and that its mRNA is expressed at high levels in the albumen gland of adult Lymnaea. The albumen gland is part of the female reproductive tract, and it secretes the perivitelline fluid that surrounds the fertilized oocytes (for review, see Joosse and Geraerts, 1983). Moreover, $L-E G F$ mRNA is expressed throughout embryonic development. With regard to neurogenesis it is interesting to note that, at stage E3, cell groups from the ectodermal epithelium begin to differentiate into ganglion cells and the first elements of the nervous system appear (Verdonk, 1973; Croll and Voronezhskaya, 1996). Thus, L-EGF is already expressed during the earliest stages of neurogenesis. This notion is further supported by preliminary RP-HPLC and mass spectrometry data indicating that intact L-EGF is present in the egg masses, from either embryonic or maternal origin (G. T. Nagle, unpublished observations). Together, this strongly suggests a role for L-EGF during embryonic development of Lymnaea.

In addition to the albumen gland, high levels of $L-E G F$ mRNA are expressed in the CNS of animals 3-4 weeks after hatching. In Lymnaea, development of the CNS is incomplete at hatching, and neuronal proliferation, circuit formation, and other developmental phenomena continue for 6-8 weeks after hatching (Croll and Chiasson, 1989; Smit et al., 1992; Serfozo et al., 1998; Croll et al., 1999). Thus, the expression of L-EGF in the CNS during extraovular development of the nervous system strongly suggests a role of L-EGF in maturation of the juvenile CNS. Together, our data suggest neurotrophic and proliferative roles for L-EGF both during the development of the Lymnaea embryo and in the juvenile CNS. This view complements studies in mammals that point to proliferative and neurotrophic roles for vertebrate EGF during CNS development (for review, see Plata-Salamán, 1991; Yamada et al., 1997). For example, mammalian EGF is thought to be involved in the regulation of cell proliferation and differentiation (for review, see Gage et al., 1995; Weiss et al., 1996; Temple and AlvarezBuylla, 1999), as well as in the survival and process outgrowth of embryonic neurons (Morrison et al., 1987; Abe et al., 1991; Casper et al., 1991; Maiese et al., 1993).

\section{Neurotrophic actions of L-EGF}

Whereas some neurotrophic actions of vertebrate EGF in the developing CNS are described (see above), the neurotrophic function of EGF in the adult CNS is less well defined. In our study, mRNA expression of $L-E G F$ was not detectable in the acutely isolated adult CNS. However, L-EGF is transcribed in the adult CNS after it was isolated (a procedure that axotomizes most neurons) and maintained for $24 \mathrm{hr}$ in organ culture. Thus, our data imply that L-EGF is involved in injury response in the adult CNS. This is supported by our observation that L-EGF supports neurite outgrowth from adult Lymnaea neurons and the report that L-EGF, in a concentration range of 400-800 nM, can support soma-soma synapse formation of adult Lymnaea neurons in vitro (Hamakawa et al., 1999). The only other suggestion for such a role of EGF is by Toma et al. (1992) who showed spatiotemporal upregulation of the EGFR in Schwann cells and fibroblasts after transection of the sciatic nerve in adult rats. This observation indicates that EGF or one of the other EGFR ligands (e.g., TGF $\alpha$, amphiregulin, betacellulin, epiregulin, and heparin-binding epidermal growth factor-like factor) (for review, see Riesse and Stern, 1998), might enhance axonal regeneration.

We showed that L-EGF is able to differentially induce neurite outgrowth in Lymnaea neurons. The specificity of L-EGF in vitro appears to differ from both murine NGF and rat CNTF. Whereas L-EGF induced neurite outgrowth primarily in Lymnaea motoneurons, both NGF and CNTF induced neurite outgrowth in motoneurons and interneurons (Ridgway et al., 1991; Syed et al., 1996). CNTF also induced neurite outgrowth in a small percentage of neurosecretory cells. Together, these studies suggest that, at least in vitro, growth factor receptors are differentially expressed in Lymnaea neurons. Furthermore, it suggests that some adult molluscan neurons express multiple growth factor receptors, a feature shared with many mammalian neurons (Korsching, 1993).

\section{L-EGF signaling}

Given that EGF acts via a tyrosine kinase receptor in vertebrate cells, we assayed the effects of protein kinase inhibitors on L-EGFevoked neurite outgrowth. We showed that L-EGF-induced neurite outgrowth of RPA neurons can be inhibited by a broadspectrum protein kinase inhibitor, K-252a (Kase et al., 1986, 1987; Ruegg and Burgess, 1989; Knüsel and Hefti, 1992). This is consistent with findings by others showing that EGF-dependent actions on primary cultures of hippocampal and cerebellar neurons can be inhibited by K-252a (Abe et al., 1992).

An even more convincing indication for the involvement of an EGFR in L-EGF-evoked neurite outgrowth is the demonstration that PD153035, reported to be a specific inhibitor of the EGFR (Fry et al., 1994; Tropepe et al., 1999), inhibits L-EGF-induced neurite outgrowth in RPA motoneurons. In view of the specificity of the inhibitor, our observation that hEGF-induced neurite out- 
growth can be inhibited by PD153035 indicates that L-EGF and hEGF act via the same receptor. Intriguingly, PD153035 did not affect CM-induced neurite outgrowth in RPA motoneurons. This could indicate that either L-EGF is not present in CM and other growth factors with overlapping activities fully substitute for the absence of L-EGF, or L-EGF is present but its neurotrophic actions are masked by other growth factors present in CM. Alternatively, it may indicate that $\mathrm{CM}$ does not contain functional L-EGF because of its degradation during production of CM (Ridgway et al., 1991). The hypothesis that L-EGF is present in CM, whether in active or inactive form, corresponds more closely with the observation that $L-E G F$ mRNA expression is upregulated in organ-cultured CNS, i.e., the source of CM-contained growth factors. Moreover, this idea is supported by our observation that L-EGF-induced neurite outgrowth is morphologically different from CM-induced outgrowth in the same types of cells, as well as by another study implicating other types of growth factors in the control of neurite outgrowth in Lymnaea (Ridgway et al., 1991).

In conclusion, our data introduce L-EGF as the first secreted form of EGF in invertebrates and suggest the involvement of L-EGF in injury response. Furthermore, high levels of L-EGF mRNA expression in ovo as well as in juvenile CNS suggests a significant role for this peptide in development of the Lymnaea nervous system. Moreover, our results indicate that the neurotrophic actions of EGF are likely to have an ancient origin. In view of the apparent absence of neurotrophin family homologs in invertebrates, this raises the question as to whether the neurotrophic actions of EGF evolved preceding those of other families of neurotrophic factors.

\section{REFERENCES}

Abe K, Takayanagi M, Saito H (1991) Basic fibroblast growth factor and epidermal growth factor promote survival of primary cultured cerebellar neurons from neonatal rats. Jpn J Pharmacol 56:113-116.

Abe K, Takayanagi M, Saito H (1992) Neurotrophic effects of epidermal growth factor on cultured brain neurons are blocked by protein kinase inhibitors. Jpn J Pharmacol 59:259-261.

Bell GI, Fong NM, Stempien MM, Wormsted MA, Caput D, Ku LL, Urdea MS, Rall LB, Sanchez-Pescador R (1986) Human epidermal growth factor precursor: cDNA sequence, expression in vitro and organization. Nucleic Acid Res 14:8427-8446.

Carpenter G, Cohen S (1990) Epidermal growth factor. J Biol Chem 265:7709-7712.

Casper D, Mytilineou C, Blum M (1991) EGF enhances the survival of dopamine neurons in rat embryonic mesencephalon primary cell culture. J Neurosci Res 30:372-381.

Chomczynski P, Sacchi N (1987) Single step method of RNA isolation by acid guanidinium thiocyanate-phenol-chloroform extraction. Anal Biochem 162:156-159.

Coligan JE, Dunn BM, Ploegh HL, Speicher DW Wingfield PT (1996) Current protocols in protein science. New York: Wiley.

Croll RP, Chiasson BJ (1989) Postembryonic development of serotoninlike immunoreactivity in the central nervous system of the snail, Lymnaea stagnalis. J Comp Neurol 280:122-142.

Croll RP, Voronezhskaya EE (1996) Early elements in gastropod neurogenesis. Dev Biol 173:344-347.

Croll RP, Voronezhskaya EE, Hiripi L, Elekes K (1999) Development of catecholaminergic neurons in the pond snail, Lymnaea stagnalis. II. Postembryonic development of central and peripheral cells. J Comp Neurol 404:297-309.

Davis CG (1990) The many faces of epidermal growth factor repeats. New Biol 2:410-419.

Derynck R, Roberts AB, Winkler ME, Chen EY, Goeddel DV (1984) Human transforming growth factor-alpha: precursor structure and expression in E. coli. Cell 38:287-297.

Engel J (1989) EGF-like domains in extracellular matrix proteins: localized signals for growth and differentiation? FEBS Lett 251:1-7.

Fainzilber M, Smit AB, Syed NI, Wildering WC, Hermann PM, Van der Schors RC, Jiménez C, Li KW, Van Minnen J, Bulloch AGM, Ibáñez CF Geraerts WPM (1996) CRNF, a molluscan neurotrophic factor that interacts with the p75 neurotrophin receptor. Science 274:1540-1543.

Fry DW, Kraker AJ, McMichael A, Ambroso LA, Nelson JM, Leopold WR, Connors RW, Bridges AJ (1994) A specific inhibitor of the epidermal growth factor tyrosine kinase. Science 265:1093-1095.

Gage FH, Coates PW, Palmer TD, Kuhn HG, Fisher LJ, Suhonen JO, Peterson DA, Suhr ST, Ray J (1995) Survival and differentiation of adult neuronal progenitor cells transplanted to the adult brain. Proc Natl Acad Sci USA 95:11879-11883.

Greenwald I (1990) Genetic and molecular analysis of EGF-related genes in Caenorhabditis elegans. Mol Reprod Dev 27:73-79.
Hamakawa T, Woodin MA, Bjorgum MC, Painter SD, Takasaki M, Lukowiak K, Nagle GT, Syed NI (1999) Excitatory synaptogenesis between identified Lymnaea neurons requires extrinsic trophic factors and is mediated by receptor tyrosine kinases. J Neurosci 19:9306-9312.

Hawke DH, Yuan PM (1987) S-pyridylethylation of cysteine residues. Applied Biosystems User Bulletin \#28, Foster City, CA.

Joosse J, Geraerts WPM (1983) Endocrinology. In: The mollusca, Vol 4, Physiology, Pt 1 (Saleuddin ASM, Wilbur KM, eds). New York: Academic.

Kase H, Kazuyuki I, Matsuda Y (1986) K-252a, a potent inhibitor of protein kinase $\mathrm{C}$ from microbial origin. J Antibiot (Tokyo) 34:1059-1065.

Kase H, Iwashi I, Nakanishi S, Matsuda Y, Yamada K, Takashi M, Murakata C, Sato A, Kaneko M (1987) K-252 compounds, novel and potent inhibitors of protein kinase $\mathrm{C}$ and cyclic nucleotide-dependent kinases. Biochem Biophys Res Commun 142:436-440.

Kaslow DC, Quakyi IA, Syin C, Raum MG, Keister DB, Coligan JE, McCutchan TF, Miller LH (1988) A vaccine candidate from the sexual stage of human malaria that contains EGF-like domains. Nature 333:74-76.

Knüsel B, Hefti F (1992) K-252 compounds: modulators of neurotrophin signal transduction. J Neurochem 59:1987-1996.

Korsching S (1993) The neurotrophic factor concept: a reexamination. J Neurosci 13:2739-2748.

Lazar L, Blum M (1992) Regional distribution and developmental expression of epidermal grow th factor and transforming growth factor- $\alpha$ mRNA in mouse brain by a quantitative nuclease protection assay. J Neurosci 12:1688-1697.

Lewis J (1996) Neurogenic genes and vertebrate neurogenesis. Curr Opin Neurobiol 6:3-10.

Magoski NS, Bulloch AGM (1997) Localization, physiology, and modulation of a molluskan dopaminergic synapse. J Neurobiol 33:247-264.

Maiese K, Boniece I, DeMeo D, Wagner JA (1993) Peptide growth factors protect against ischemia in culture by preventing nitric oxide toxicity. J Neurosci 13:3034-3040.

Morrison RS, Kornblum HI, Leslie FM, Bradshaw RA (1987) Trophic stimulation of cultured neurons from neonatal rat brain by epidermal growth factor. Science 238:72-75.

Muskavitch MAT, Hoffmann FM (1990) Homologs of vertebrate growth factors in Drosophila melanogaster and other invertebrates. Curr Top Dev Biol 24:289-328.

Neuman-Silberberg FS, Schüpbach T (1993) The Drosophila dorsoventral patterning gene gurken produces a dorsally localized RNA and encodes a TGF $\alpha$-like protein. Cell 75:165-174.

Plata-Salamán CR (1991) Epidermal growth factor and the nervous system. Peptides 12:653-663.

Plowman GD, Green JM, McDonald VL, Neubauer MG, Disteche CM, Todaro GJ, Shoyab M (1990) The amphiregulin gene encodes a novel epidermal growth factor-related protein with tumor-inhibitory activity. Mol Cell Biol 10:1969-1981.

Rall LB, Scott J, Bell GI, Crawford RJ, Penschow JD, Niall HD, Coghlan JP (1985) Mouse prepro-epidermal growth factor synthesis by the kidney and other tissues. Nature 313:228-231.

Ridgway RL, Syed NI, Lukowiak K, Bulloch AGM (1991) Nerve growth factor (NGF) induces sprouting of specific neurons of the snail, Lymnaea stagnalis. J Neurobiol 22:377-390.

Riesse II DJ, Stern DF (1998) Specificity within the EGF family/ErbB receptor family signaling network. BioEssays 20:41-48.

Roovers E, Vincent ME, Van Kesteren E, Geraerts WP, Planta RJ, Vreugdenhil E, Van Heerikhuizen H (1995) Characterization of a putative molluscan insulin-related peptide receptor. Gene 162:181-188.

Ruegg UT, Burgess GM (1989) Staurosporine, K-252a and UCN-01: potent but nonspecific inhibitors of protein kinases. Trends Pharmacol Sci 10:218-220.

Rutledge BJ, Zhang K, Bier E, Jan YN, Perrimon N (1992) The Drosophila spitz gene encodes a putative EGF-like growth factor involved in dorsal-ventral axis formation and neurogenesis. Genes Dev 6:1503-1517.

Sachs L (1982) Applied statistics. A handbook of techniques, Ed 2. New York: Springer.

Savage Jr CR, Inagami T, Cohen S (1972) The primary structure of epidermal growth factor. J Biol Chem 247:7612-7621.

Savage Jr CR, Hash JH, Cohen S (1973) Epidermal growth factor. Location of disulfide bonds. J Biol Chem 248:7669-7672.

Schaudies RP, Christian EL, Savage Jr CR (1989) Epidermal growth factor immunoreactivity material in the rat brain. Localization and identification of multiple species. J Biol Chem 264:10447-10450.

Serfozo Z, Elekes K, Varga V (1998) NADPH-diaphorase activity in the nervous system of the embryonic and juvenile pond snail, Lymnaea stagnalis. Cell Tissue Res 292:579-586.

Smit AB, Jiménez CR, Dirks RW, Croll RP, Geraerts WPM (1992) Characterization of a cDNA clone encoding multiple copies of the neuropeptide APGWamide in the mollusc Lymnaea stagnalis. J Neurosci 12:1709-1715.

Smith JS, Miller BT, Knock SL, Kurosky A (1991) Biotinylated peptides/ proteins. I. Determination of stoichiometry of derivation. Anal Biochem 197:247-253.

Syed N, Richardson P, Bulloch AGM (1996) Ciliary neurotrophic factor, 
unlike nerve growth factor, supports neurite outgrowth but not synapse formation by adult Lymnaea neurons. J Neurobiol 29:293-303.

Taylor JM, Mitchell WM, Cohen S (1972) Epidermal growth factor. Physical and chemical properties. J Biol Chem 247:5928-5934.

Temple S, Alvarez-Buylla A (1999) Stem cells in the adult mammalian central nervous system. Curr Opin Neurobiol 9:135-141.

Toma JG, Pareek S, Barker P, Mathew TC, Murphy RA, Acheson A, Miller FD (1992) Spatiotemporal increases in epidermal growth factor receptors following peripheral nerve injury. J Neurosci 12:2504-2515.

Tropepe V, Sibilia M, Ciruna BG, Rossant J, Wagner EF, Van der Kooy D (1999) Distinct neural stem cells proliferate in response to EGF and FGF in the developing mouse telencephalon. Dev Biol 208:166-188.

Van de Poll MLM, Van Vugt MJH, Lenferink AEG, Van Zoelen EJJ (1998) Identification of the minimal requirements for binding to the human epidermal growth factor (EGF) receptor using chimeras of human EGF and an EGF repeat of Drosophila Notch. J Biol Chem 273:16075-16081.

Van Kesteren RE, Fainzilber M, Hauser G, Van Minnen J, Vreugdenhil E,
Smit AB, Ibáñez CI, Geraerts WPM, Bulloch AGM (1998) Early evolutionary origin of the neurotrophin receptor family. EMBO J $17: 2534-2542$.

Verdonk NH (1973) Gene expression in early development of Lymnaea stagnalis. Dev Biol 35:29-35.

Von Heijne G (1983) A new method for predicting signal sequence cleavage sites. Nucleic Acid Res 14:4683-4690.

Weiss S, Reynolds BA, Vescovi AL, Morshead C, Craig CG, Van der Kooy D (1996) Is there a neural stem cell in the mammalian forebrain? Trends Neurosci 19:387-393.

Wildering WC, Lodder JC, Kits KS, Bulloch AGM (1995) Nerve growth factor (NGF) acutely enhances high-voltage activated $\mathrm{Ca}^{2+}$ currents in adult molluscan neurons. J Neurophysiol 74:2778-2781.

Wildering WC, Hermann PM, Bulloch AGM (1998) Neurite outgrowth, RGD-dependent, and RGD-independent adhesion of identified molluscan motoneurons on selected substrates. J Neurobiol 35:37-52.

Yamada M, Ikeuchi T, Hatanaka H (1997) The neurotrophic action and signalling of epidermal growth factor. Prog Neurobiol 51:19-37. 